\title{
Topraksız Fasulye Kültüründe Azotun Rhizobium Bakteri Nodülasyonu ve Bitki Gelişmi Üzerine Etkisi
}

\author{
*Onur Sinan TÜRKMEN Fatih ÖZÇELIK Ömer NIZAM Harun BAYTEKIN \\ Çanakkale Onsekiz Mart Üniversitesi, Ziraat Fakültesi, Tarla Bitkileri Bölümü, Çanakkale \\ *Sorumlu yazar e-posta (Corresponding author e-mail): onurturkmen@comu.edu.tr
}

\section{Öz}

Bu çalışmada perlit kültüründe azotun ve bakteri aşılamasının, fasulyenin (Phaseolus vulgaris) gelişimi üzerine etkisi araştııılmıştır. Çalışma kontrollü ortamda yürütülerek besi solüsyonu olarak modifiye Hoagland kullanılmış; azot ve Rhizobium tropici bakteri suşu değişken olarak denenmiştir. Araştırmada, azotlu gübre, bakteri aşılaması, gübre+aşılama birlikte yapılan ve kontrol olmak üzere dört uygulama kullanılmıştır. Yalnızca bakteri uygulanan grupta bitki başına ortalama 92.88 adet/bitki nodül oluşumu gözlenirken diğer hiçbir grupta bakteri gelişimi gözlenmemiştir. En yüksek baklada dane sayısına, gübre+aşılama yapılan grupta ulaşılmıştır. Azot ve aşılama uygulanmayan grupta, bakla ve dane verimi yönünden daha düşük değerler elde edilmiştir.

Anahtar Kelimeler: Su kültürü, nodülasyon, baklagil, azotlu gübreleme

\section{Effect of Nitrogen Fertilization and Rhizobium on Hydroponic Bean Culture}

\begin{abstract}
The study was conducted to evaluate the effects of nitrogen and bacteria inoculation on common bean growing (Phaseolus vulgaris) under perlite culture conditions. Modified Hoagland solution was used as medium, nitrogen and Rhizobium tropici bacteria strain were used as variable on controlled environments. In the research 3 treatments and control were used, namely, nitrogen fertilizer, bacteria inoculation, nitrogen+bacteria effects and without $\mathrm{N}$ and bacteria is control. Sole bacteria treatment yielded 92.88 nodules whereas none of the other applications caused nodule formation. The highest number of seeds per pod was achieved in nitrogen+bacteria application. The group which was not applied fertilizer and bacteria had less bean and seed numbers.
\end{abstract}

Keywords: Hydroponics, nodulation, legume, nitrogen fertilizer

\section{Giriş}

$\mathrm{D}^{\mathrm{in}}$ ünya nüfusunun hızlı artışı klasik tarım yöntemlerinin ihtiyaç duyulan tarım ürünleri üretimine yetmeyeceği açıktır. Bu açıdan topraksız tarım yöntemi klasik tarımsal üretim yöntemine önemli bir alternatif oluşturmaktadır. Su kültürü yöntemi, sulama suyunun etkin kullanıldığı ve bitki ihtiyacı kadar gübrenin kullanıldığı bir üretim sistemi olması sebebiyle kaynakların etkin kullanıldığı bir yöntemdir. Fakat mutlak gübre gereksinimi sebebiyle sürdürülebilir bir yöntem değildir. Ancak simbiyotik organizmaların kullanılarak bir ekolojik niş oluşturulması durumunda su kültürü sürdürülebilir bir yöntem olabilir.

Topraksız tarımı gerekli kılan en önemli sebebin nüfus artışı ve daralan tarım arazilerinin olması bu yöntemin yaygınlaşmasına neden olmaktadır. Topraksız tarımın ilk olarak 1600 'lü yıllarda Belçikalı araştırıcı Helmount, 1860'ı yıllarda Knop ve Sachs tarafından uygulandığına dair bilgiler bulunmaktadır (Hershey 1994; Sevgican 2003). En yaygın kullanılan besi ortamının geliştiricisi ise Hoagland'tır (Hoagland and Armon 1950). Su kültürü yönteminin avantajları yanında yüksek kurulum maliyeti, kesintisiz enerji bağımlığı, tuzlanma ve hızlı kök hastalıkları yayılma riski de bulunmaktadır. Diğer yandan teknik bilgiye sahip teknik personel intiyacı da bulunmaktadır. Topraksız kültür yöntemleri açısından durgun ve aeroponik, yetiştirildiği ortamlar olarak da kullanılan substratlar nitelikleri açısından katı ve su kültürü olarak gruplandırılabilir. Katı ortam kültürleri olarak perlit, hindistan cevizi kabuğu, pomza, vermikulit, torf, saman balyaları, zeolit, çakıl, kum, cam yünü, plastik köpük, talaş, kaya yünü, kavuz, bitki artık ve kabukları, organik artık 
kompostları, substrat ortamı yaygın olarak kullanılmaktadır (Asri 2010). Perlit kültürünün diğer kültür yöntemlerine göre avantajı, sistem takibi ve kurulumu kolaydır ve ortamın tuttuğu besin elementi stabil olduğundan diğer kültür ortamlarına göre beslenme yetersizliği ve havalanmaya bağlı sorunları daha azdır. Perlitin ülkemizde üretimi yaygındır ve ucuz bir materyaldir (Varış 1998).

Yemeklik dane baklagiller familyası Rhizobium bakterisiyle havanın serbest azotunu bitkiye kazandırması ile simbiyotik ortaklık içerisindedir. Köklerde yer alan bakteriyle ekim sonrası toprağın organik madde ve azot bütçesi gelişmekte, bu nedenle baklagiller iyi bir ekim nöbeti bitkisi durumuna gelmektedir. Fasulye yüksek protein miktarı ve esansiyel aminoasit içerikleri nedeniyle toplumun beslenmesi açısından önemli bir yere sahiptir. Dünyada ekimi yapılan yemeklik dane baklagil bitkileri içerisinde fasulye bitkisi, üretim alanı bakımından $\% 49$ ekim alanına ve üretim miktarı bakımından \%37'lik bir üretim hacmi oluşturur. Kuru fasulyenin ülkemizde kişi başı yıllık tüketim miktarı $3.2 \mathrm{~kg}$ 'dır. Bu oran $1.35 \mathrm{~kg} / \mathrm{kişi} / \mathrm{yıl}$ olan Avrupa'nın üzerinde $7.98 \mathrm{~kg} / \mathrm{kişi} / \mathrm{yıl}$ olan G. Amerika'nın altındadır. Dünya fasulye tüketim ortalaması ise $2.33 \mathrm{~kg} / \mathrm{kişi} / \mathrm{y}$ ıl'dır (Çiftçi, 2004). Ülkemizde fasulye bitkisi, 250 bin ton üretim ile nohut ve mercimekten sonra yemeklik tane baklagil bitkileri üretimi bakımından 3. sırada yer alır. Fasulye bitkisi için en iyi çimlenme sıcaklığı $15-20^{\circ} \mathrm{C}$, büyüme sıcaklığı ise $20-25^{\circ} \mathrm{C}$, toprak $\mathrm{pH}$ isteği ise 5.2-7.0 arasıdır. Fasulye bitkisinin etkili bakterisi, Rhizobium phaseoli ve R. tropici dir (Özdemir 2001; Çiftçi 2004).

Rhizobium nodülleri nitrogenaz enzimi yardımıyla moleküler haldeki $3 \mathrm{~mol}$ azotu, elemental azota, sonra diimid $\left(\mathrm{N}_{2} \mathrm{H}_{2}\right)$, daha sonra hidrazin'e $\left(\mathrm{N}_{2} \mathrm{H}_{4}\right)$, daha sonra ise 2 molekül amonyağa $\left(\mathrm{NH}_{3}\right)$ dönüştürür. Bu son ürün bitki tarafından amino asitlere dönüştürülür. $\mathrm{Bu}$ biyokimyasal dönüşümde kullanılan $15 \mathrm{ATP}$ bitki fotosentez ürünlerinden sağlanır (Özdemir 2002). Bitkiler tarafindan salgılanan triptofan bakteriler tarafından indol asetik asite dönüştürülür. Oksin grubundaki IAA hormonu köklerde kıvrılmaya neden olur ve kıvrılmalar sayesinde bakteri kökleri infekte ederek kök içine uzayan bir kanalla bitki içerisinde uzanan bakteri haustoriumu, bitki tarafından bir selüloz çeperle de sarılır. Azot dozunun bitki intiyacını karşılayacak düzeyde yüksek olması durumunda kök kıvrımları gerçekleşmemesi nedeniyle nodülasyon gerçekleşmez (Ülgen 1975).
Bu çalışmanın amacı konvansiyonel üretim şartlarında yaygın olarak uygulanan fasulye Rhizobium ortak yaşam formunun su kültürü ortamında incelenmesidir. Bu çalışma ile en önemli besin elementi girdilerinden azotun, simbiyotik yaşam formu ile havanın serbest azotuyla ikame edilmesi ve daha az maliyetle ve nispeten daha sürdürülebilir bir su kültürü yönteminin sunulması amaçlanmıştır.

\section{Materyal ve Yöntem}

Çalışma, Çanakkale Onsekiz Mart Üniversitesi Ziraat Fakültesi Tarla Bitkileri Bölümü Laboratuarları'nda tesadüf parselleri deneme desenine göre 8 tekerrür ve 4 farklı uygulama şeklinde gerçekleşmiştir. Tohumluk olarak Nazende erkenci fasulye çeşidi kullanılmıştır. Besi ortamı olarak azot ve potasyumun; amonyum nitrat ve potasyum hidroksit şeklinde modifiye edildiği Hoagland besi ortamı kullanılmış, pH 5.7'ye $\mathrm{H}_{2} \mathrm{SO}_{4}$ ile sabitlenmiş. Bakteri suşu olarak Rhizobacter Argentina SA firmasına ait $2 \mathrm{ml} / \mathrm{bitki} \mathrm{sIVI}$ inokulant Rhizobium tropici (1x108 UFC/mL) ve $1 \mathrm{ml} /$ bitki oranında Premax Rhizobium protector kullanılmıştır. Çimlenmesinin üzerinden on dört gün geçen bitkiler Rhizobium aşılaması yapılarak su kültürü sistemine alınmıştır.

Kültür ortamı olarak PVC boru içerisine yerleştirilen perlit kullanılmıştır (500g/uygulama). Her bir PVC yetiştirme düzeneğine yerleştirilen 8 fasulye bitkisi ucu yukarıya bağlanan iplerle desteklenmiştir. Her bir uygulamaya ait $6 \mathrm{~L}$ besi solüsyonu, $\mathrm{PVC}$ boruları içerisine arter ve lateral sulama borularıyla uygulanmış ve $500 \mathrm{~L} / \mathrm{h}(220 \mathrm{~V} / 60 \mathrm{~Hz}$ 8Watt) debideki akvaryum motoru ile devir daim yapılmıştır. Eksilen sıvı miktarı saf su ile tamamlanmıştır. Işılklandırma zamanlayıcı yardımıyla 16/8 (aydınlık /karanlık) fotoperiyod şeklinde su devir daimi ile eş zamanlı yapılmıştır. Aydınlatma beyaz florasans ışığı şeklinde 3000 lüks yoğunluğa ayarlanmıştır. Ortam sıcaklığı $24^{\circ} \mathrm{C}$ 'ye ayarlanmıştır. Kültür ortamına alınan bitkiler kırkıncı gün sonunda hasat edilmiştir.

Hasadın gerçekleşmesi ile agronomik açıdan sürgün, kök ve bakla yaş ve kuru ağırıkları, kök ve gövde uzunlukları ile nodül ve yaprak sayıları incelenmiştir. Azot analizleri ise kök, gövde ve baklada yapılmıştır. Veriler SAS paket programıyla PROG GLM prensibine göre yapılmış ve ortalamalar arasındaki farklar $\% 5$ düzeyinde LSD testine göre belirlenmiştir. 

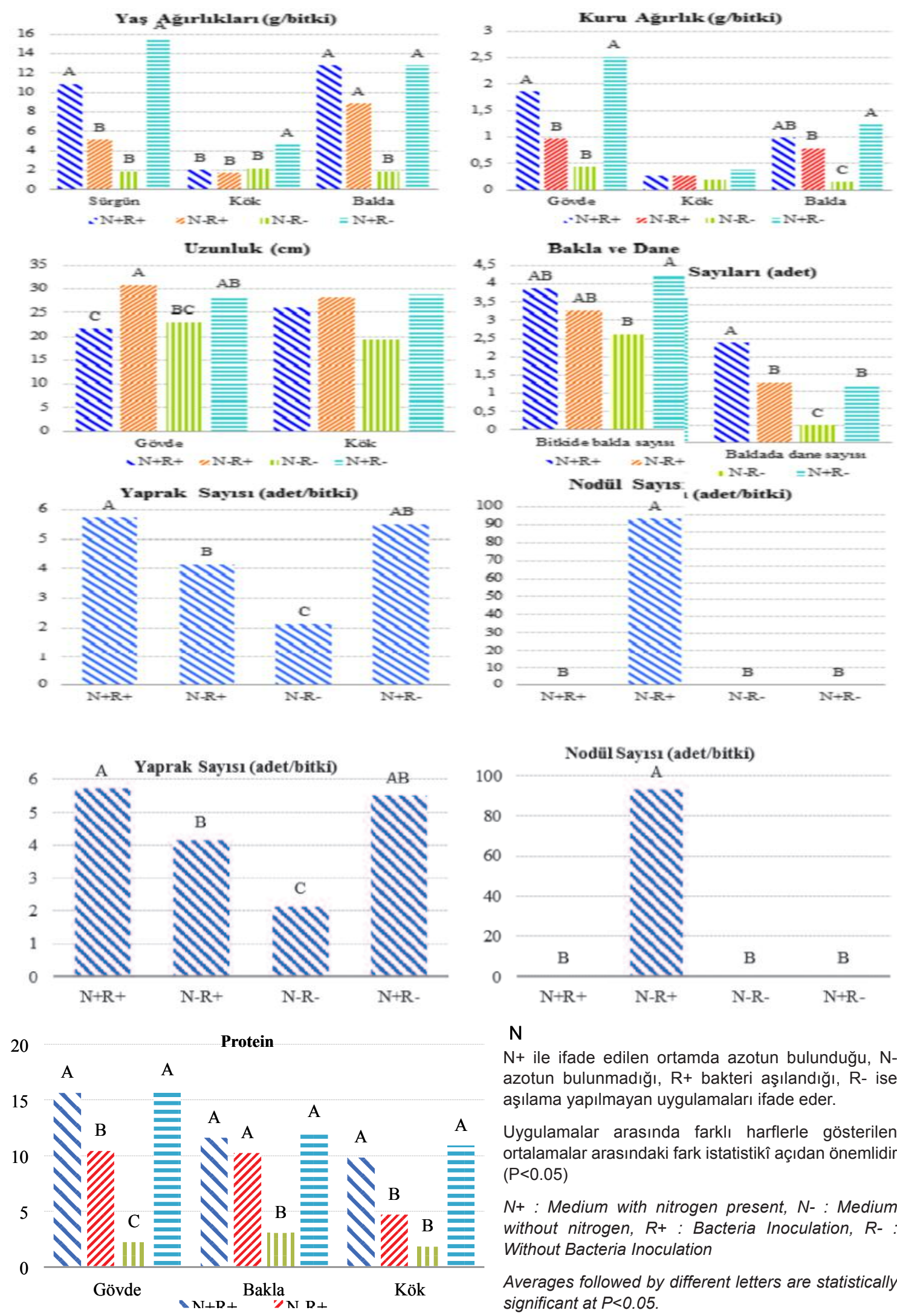

$\mathrm{N}$

$\mathrm{N}+$ ile ifade edilen ortamda azotun bulunduğu, Nazotun bulunmadığı, R+ bakteri aşılandığı, R- ise aşılama yapılmayan uygulamaları ifade eder.

Uygulamalar arasında farklı harflerle gösterilen ortalamalar arasındaki fark istatistikî açıdan önemlidir $(\mathrm{P}<0.05)$

$\mathrm{N}^{+}$: Medium with nitrogen present, $\mathrm{N}-$ : Medium without nitrogen, $R_{+}$: Bacteria Inoculation, $R-$ : Without Bacteria Inoculation

Averages followed by different letters are statistically significant at $P<0.05$.

Şekil 1. Çalışmada elde edilen verilere ait grafikler Figure 1. Graphics of data obtained from experiments 


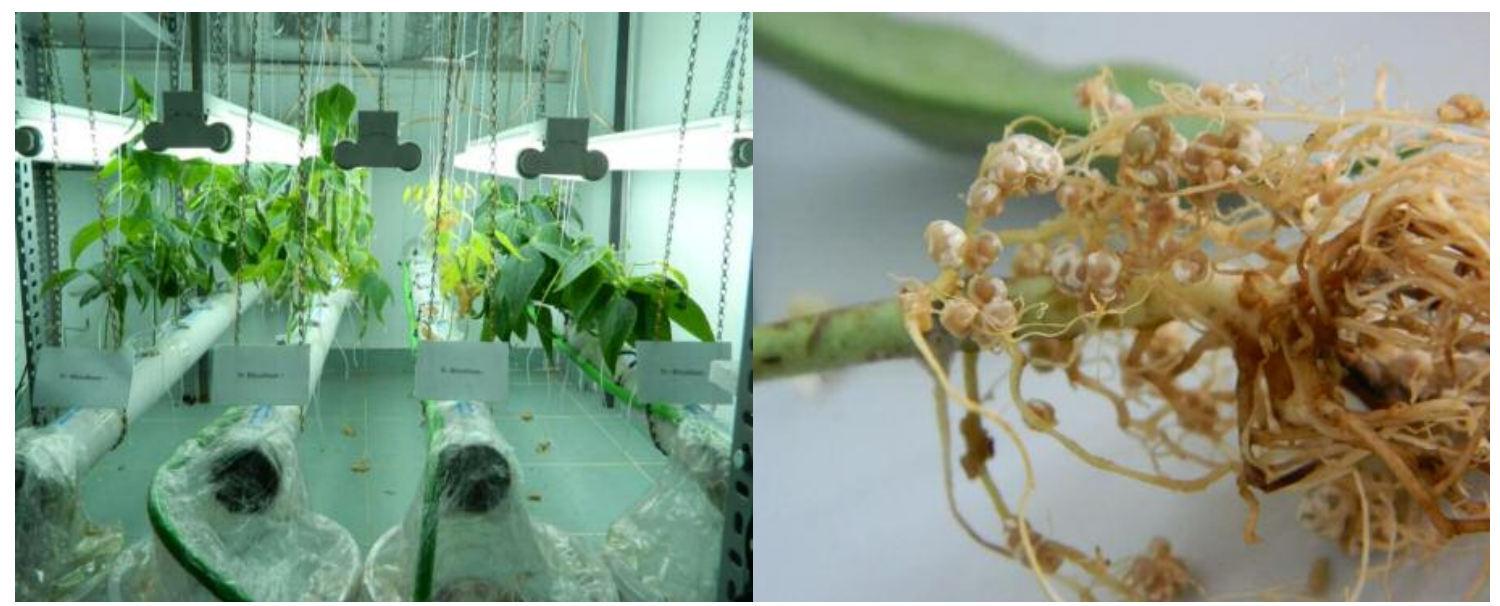

Şekil 2. Azot ve Rhizobium'un bitki gelişimi üzerindeki etkisi

Figure 2. Effects on nitrogen and Rhizobium on plant development

\section{Bulgular ve Tartışma}

İncelenen agronomik ve kalite parametreleri arasında kök uzunluğu ve kök kuru ağırığı bakımından uygulamalar arasında fark olmadığı, diğer tüm parametreler açısından önemli farkın olduğu gözlenmiştir (Şekil 1).

Hasat dönemine ait görüntüde, uygulamalar arasında oluşan farklılık açık şekilde görülmektedir. En sağdaki bakteri aşılanmayan, azot içeren uygulamanın diğer uygulamalara göre daha kısa boylu yapıya ve daha koyu yeşil, geniş yapraklara sahip olduğu görülür. Azot ve bakteri eklenmeyen sağdan ikinci uygulamada azot eksikliği nedeniyle senescence durumu gözlenmiştir. Soldaki iki kültür ortamlarına bakteri aşılaması yapıldığı en soldakinin azot içerip koyu yeşil renge sahip olduğu, yanındakinin ise azot eklenmeyip Rhizobium ile aşılandığı ve yapraklarının daha açık yeşil renge sahip olduğu görülmektedir. Uzun boylu görünmesinin nedeni Rhizobium bakterisinin bitkiye sağladığı sitokinin hormonundan kaynaklıdır (Ülgen, 1975). Sağdaki fotoğrafta ise azot içermeyen bakteri aşılama yapılan uygulamada köklere inoküle olmuş Rhizobium bakterileri görülmektedir (Şekil 2.).

Bakteri aşılaması yapılan iki uygulamadan azot bulunmayan kültür ortamında Rhizobium aktivitesi gözlenirken (92.88 nodül/bitki) diğer hiçbir uygulamada nodül oluşumuna rastlanmamıştır. Ortamda bitkinin intiyaç duyduğu oranda azotun bulunması Rhizobium bakteri aktivitesini kısıtladığı görülmektedir (Ülgen 1975). Azot bulunmayan ortama bakteri aşılamasının bitkiye önemli derece azot sağladığı ancak bu katkının, bitkide bakla sayısı ve bakla protein oranı dışındaki diğer incelenen özellikler açısından azot intiva eden uygulamalar kadar yeterli olmadığı görülmüştür. Rhizobium eklenen ve azot intiva eden ortamda nodülasyon gerçekleşmesinin sebebi bitkinin azot eksikliği yaşamamış ve strese girmemiş olması nedeniyle de Rhizobium un inokülasyon gerçekleşmnesi için gerekli salgıyı salgılamamış olmasıdır.

\section{Sonuç}

Azotun yer aldığı iki kültür ortamında Rhizobium faktörünün gövde uzunluğu ve kök yaş ağırlığı üzerine etkili olduğu bu iki uygulamada bakteri faktörünün sayısal bir düşüşe neden olduğu ancak baklada dane sayısında önemli bir artışın olduğu görülmüştür. Azot bulunan ortama bakteri aşılamasının incelenen diğer parametreler bakımından önemli istatistiksel farka neden olmadığı tespit edilmiştir.

\section{Kaynaklar}

Asri F.Ö., 2010. Topraksız Tarım. Tarım ve Köy İşleri Bakanlığı Çiftçi Eğitim Yayın Dairesi Başkanlığı Yayın No: 59, s. 36

Çiftçi C..Y, 2004. Dünya'da ve Türkiye'de yemeklik tane baklagiller tarımı. TMMOB Ziraat Mühendisleri Odası Teknik Yayınlar Dizisi No: 5 Kızılay/Ankara, 200s.

Hoagland D.R. and Arnon D.I., 1950. The waterculture method for growing plants without soil. California Agriculture Experiment Station Circular, p. 347

Hershey D.R., 1994. Solution culture hydroponics: History and inexpensive equipment. The American Biology Teacher, 56(2): 111-118. 
Türkmen et al. "Effect of Nitrogen Fertilization and Rhizobium on Hydroponic Bean Culture"

Özdemir S., 2002. Yemeklik Baklagiller. Hasad Yayıncılık, Kadıköy-İstanbul, 223s

Sevgican A., 2003. Örtüaltı Sebzeciliği (Topraksız Tarım) (2. Baskı). Ege Üni. Ziraat Fak. Yayınları No. 526, Ege Üni. Basımevi Bornova İzmir, 168s

Ülgen H., 1975. Baklagil Bitkilerinin Nodül Bakterileri (Rhizobium) ile Aşılanması. T.C. Köyişleri Bakanlığı Toprak Su Genel Müdürlüğü Toprak ve Gübre Araştırma Enstitüsü Yayınları, No: 56, S: 44, Ankara
Varış S., 1998. Sera Sebzelerinin Perlit Doldurulmuş Torbalarda Topraksız Yetiştirilmesi (3. Baskı). Trakya Üni. Tekirdağ Ziraat Fak. Yayınları No: 128, S: 15 